\title{
Preserving Socioemotional Wealth of Small and Medium- Sized Family Businesses: A Propose Framework
}

Kong Lai Kuan, Ju Soon Yew, Nurul Nadia Abd Aziz, Nor Khairunnisa Mat Yunus, Zaidatul Nadiah Abu Yazid

To Link this Article: http://dx.doi.org/10.6007/IJARBSS/v11-i11/11144

DOI:10.6007/IJARBSS/v11-i11/11144

Received: 07 September 2021, Revised: 30 September 2021, Accepted: 16 October 2021

Published Online: 03 November 2021

In-Text Citation: (Kuan et al., 2021)

To Cite this Article: Kuan, K. L., Yew, J. S., Aziz, N. N. A., Yunus, N. K. M., \& Yazid, Z. N. A. (2021). Preserving Socioemotional Wealth of Small and Medium-Sized Family Businesses: A Propose Framework. International Journal of Academic Research in Business and Social Sciences, 11(11), 31-41.

Copyright: (c) 2021 The Author(s)

Published by Human Resource Management Academic Research Society (www.hrmars.com)

This article is published under the Creative Commons Attribution (CC BY 4.0) license. Anyone may reproduce, distribute, translate and create derivative works of this article (for both commercial and non-commercial purposes), subject to full attribution to the original publication and authors. The full terms of this license may be seen at: http://creativecommons.org/licences/by/4.0/legalcode

Vol. 11, No. 11, 2021, Pg. $31-41$

Full Terms \& Conditions of access and use can be found at http://hrmars.com/index.php/pages/detail/publication-ethics 


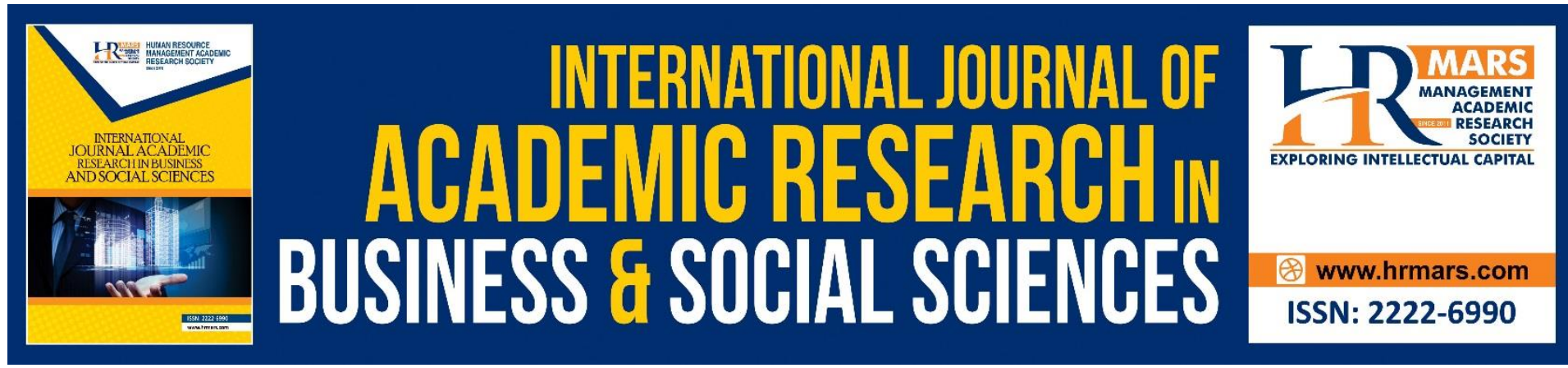

\title{
Preserving Socioemotional Wealth of Small and Medium-Sized Family Businesses: A Propose Framework
}

Kong Lai Kuan (Dr. $)^{1}$, Ju Soon Yew (Dr.) $)^{2}$, Nurul Nadia Abd Aziz (Dr.) ${ }^{3}$, Nor Khairunnisa Mat Yunus ${ }^{4}$, Zaidatul Nadiah Abu Yazid $^{5}$

1,3,4,5 Faculty of Business and Management, Universiti Teknologi Mara (UiTM) Pahang Branch, Raub Campus, 27600 Raub Pahang Malaysia, ${ }^{2}$ Faculty of Administrative Science and Policy Studies, Universiti Teknologi Mara (UiTM) Pahang Branch, Raub Campus, 27600 Raub Pahang Malaysia

\begin{abstract}
Family businesses are found to acquired non-economic goals as compared to their business counterparts. Nevertheless, small and medium-sized family businesses are found to be facing challenges such as limited inter-knowledge sharing, lack of strategic succession planning and technology adoption that might hinder their goals achievement and sustainability. Thus, this research aims to propose a framework as to preserve the socioemotional wealth of small and medium-sized family businesses through family resources and capability such as knowledge sharing, succession planning and technology readiness. This study also proposes to test the moderating role of technology readiness in the relationship of knowledge sharing and succession planning toward socioemotional wealth of small and medium-sized family business.
\end{abstract}

Keywords: Socioemotional Wealth, Small and Medium-Sized Family Businesses, Knowledge Sharing, Succession Planning, Technology Readiness.

\section{Introduction}

This study aims to propose a framework that uitlise family-specific resources and capability to preserve the socioemotional wealth of small and medium-sized family businessess. Family business's scholars have long found that financial goals are not necessarily the ultimate aims that to be pursued by family businesses, instead, due to family consideration, they might pursue non-economic goals as well (Astrachan \& Jaskiewicz, 2008; Debicki, 2012; Sharma et al., 1997; Westhead \& Cowling, 1998), which is the socioemotional wealth. However, their survival rate and sustainability are in doubt as researches indicated that many family businesses are still running by first and second generations. For instance, PwC Global Family Business Survey (2018) shows that out of about 2916 respondents across 53 territories, 72 percent of the family businesses are running by first and second generations. In Malaysia context, PwC Global Family Business Survey 2018: The Malaysian Chapter (2019) 
has noticed that most of the active Malaysian family businesses are in the second or third generation stages. Poza (2004) has noted that about $85 \%$ of all family businesses failed within their first five years of operation and among those survived, only $30 \%$ have successfully transferred to the second generation of the founding family owners.

This phenomenon arose a concern on the survival and longevity of family business, in particularly the small and medium-sized family businesses (SMFBs) that majority of SMEs are having insufficient resources such as lack of skilful workers, little finance resources and adoption of technology (Omar, 2019; Prasanna et al., 2019). Yet, they are the main business players in almost all nations. However, SMFBs are having obvious uniqueness and complexity as compared to its non-family business counterparts that family business has the involvement and influence of family in the business (Chua et al., 1999). Against these backdrops, this study proposed a framework that integrates the family-specific resources and capability into the SMFBs in preserving the socioemotional wealth (SEW). This research proposes that knowledge sharing, succession planning and technology readiness could serve as familyspecific resources and capability to attain socioemotional wealth of SMFBs.

\section{Socioemotional Wealth}

This SEW concept first emerged in 2007 where scholars defined it as "the non-financial aspects of the firm that meet the family's affective need" (Gomez-Mejia et al., 2007, p.6). Those aspects of SEW are for examples: close identification of family members with the business, preservation of family image and reputation, care about the firm's perpetuation, desires of family members to influence decision, and concern for acquaintances and community relations (Mejia et al., 2007); family reputation, family sustainability and family obligations (Debicki, 2012), emotional values (Astrachan \& Jaskiewicz, 2008), family harmony, social status, and identity (Chrisman et al., 2012); 'dynasting' the family business (Loy, 2010); increasing the well-being of the family through providing employment for family members, perpetuation of family values through the business as well as psychological benefits of belonging, intimacy, and affection (Gomez-Mejia et al., 2007; Jones et al., 2008), and control, continuity, family pride, harmony, trustful relations, family reputation, sense of belonging, and cohesion (Ward, 1997).

Berrone, Cruz, and Gómez-Mejía, (2012) proposed 5 dimensions of SEW, namely FIBER scale, which included the aspects of Family control and influence, Identification of family members with the family business, Binding social ties, Emotional attachment of family members, and Renewal of family bonds to the firm through dynastic succession with 30 items that reviewed and accumulated from previous scales used to assess each of these dimensions. Debicki et al (2016) updated the SEW measurement called SEWi as to measure family businesses owners and manager preferences toward family prominence, family continuity, and family enrichment.

SEW is believed to exist within family members, influence unique family business decisions and behaviours, and thus, capture the essence of what distinctive family business phenomena from that of non-family business (Jiang et al., 2018). A wealth of studies indicated that preserving family sustainability or business control of SEW aspects is also the goal that Malaysian family business desired (Loy, 2010; PwC Global Family Business Survey: Focus on Malaysia, 2015). PwC Global Family Business Survey: Focus on Malaysia (2015) also noticed that family and non-family members in the Malaysian family businesses have different 
priorities whereby family members are more concerned about personal legacy that is to ensure the business stays in the family and creates employment for other family members. Furthermore, the same survey found that $38 \%$ of their respondents are looking to pass on management to the next generation while $36 \%$ are looking to pass on ownership, but bring professional managers in. Recently, research revealed that $80 \%$ of Malaysia family businesses want to protect the business as the important family asset and $73 \%$ want to ensure the business stays in the family (PwC Family Business Survey 2018: The Malaysian Chapter). Unfortunately, while many family business researches focus on the effect of SEW towards family business's performance (i.e., financial performance, internationalization, debt financing, innovation (Alonso-Dos-Santos, \& Llanos-Contreras, 2019; Baixauli-Soler et al., 2021; Debicki et al., 2017; Hauck and Prügl, 2015; Németh, \& Németh, 2018), or either as moderator (Schepers et al., 2014), little research studied the factors influencing SEW. As such, this study proposed that knowledge sharing among the family members could plays an important role in attaining the SEW.

\section{Knowledge Sharing}

Knowledge sharing can be defined as the exchange of task-related information, advice and expertise to help others and to cooperate with others to conduct daily tasks, solve problems and develop new ideas (Ahmad, 2017). It plays a prominent role for an organization to develop its knowledge resources for better business performance (Cunningham, Seaman, \& Mcguire, 2017). Its improved the organization in the aspects of work-quality, decisionmaking skills, problem-solving efficiency, and competency (Syed-lkhsan \& Rowland, 2004; Yang, 2007), reduction in production costs, faster completion of new product development projects, team performance, firm innovation capabilities, and firm performance including sales growth, and revenue from new products and services (Wang \& Noe, 2010). Therefore, when knowledge sharing is limited across an organization, the likelihood of increase of knowledge gaps is high and these gaps are likely to produce less-than-desirable work outcomes (Baird \& Henderson, 2001). Apparently, knowledge sharing between individuals and departments in the organization is critically important (O'Dell \& Grayson, 1998).

Unfortunately, some family businesses believed that knowledge is power that should not be shared. Therefore, they do not participate in the knowledge network (Ahmad \& Daghfous, 2010) and/or developed their own network structure that exclude outsider (Lin, 2013). These might result in limited access to resources such as external knowledge (Miller et al., 2010; Schulze et al., 2001). On the other hand, tacit knowledge is found to be transferred and developed across generations within the family in a way that makes it not only difficult to imitate by other firms, but also hard to utilize by managers who are non-family members (Cabrera-Suárez, De Saá-Pérez, \& García-Almeida, 2001; Chirico, 2008a). Family relationship, trust, commitment, and psychological ownership make the information flow easy in between and within generations in family business, which might not be easily achieved in non-family businesses (Chirico, 2008b) as well. Obviously, knowledge sharing in family business is practised selectively that they preferred to share knowledge internally than with outsiders and the posses of knowledge resources in family firms are often built up over a long period of time and across family generations in ways that make them rare and difficult to imitate or substitute thereby a source of superior performance (Cabrera-Suárez et al., 2001; Eddleston, Kellermanns, \& Sarathy, 2008). Thus, it is believed that the ability to acquire, develop, share, transfer, and apply knowledge enables a family business to generate higher value of 
performance over time (Cabrera-Suárez et al., 2001; Grant, 1996), in particularly when the new generation is integrated into the family business and the transfer of knowledge from the previous generation to the next takes place (Cabrera-Suárez et al., 2001; Chirico, 2008a \& $2008 \mathrm{~b})$. On top of that, it was also found that early involvement of children in the family firm can produce deeper levels of firm-specific tacit knowledge (Sirmon \& Hitt, 2003). As such, besides sharing knowledge, succession planning is also necessary as to ensure the transferring of valuable knowledge within the family business.

\section{Succession Planning}

"Succession: Failing to plan means planning to fail" - PwC Family Business Survey (2016)

Rothwell (2001) defined succession planning as an organization's effort to make sure the continuity of leadership in key positions, retain and develop intellectual and knowledge capital for the future, and encourage individual advancement. PwC Family Business Survey (2016) suggested that "the most obvious potential 'failure factor' for the family firm is the succession process". PwC Family Business Survey 2018: The Malaysian Chapter (2019) revealed that critical issues in the Malaysia family business are succession planning and growth as only a mere $23 \%$ of Malaysia's respondents have a robust, formalised and communicated succession plan in place. Although succession planning is highly considered by the leading members of the large sized family businesses, in the small and medium-sized family businesses, this idea is not completely implemented (Cho, Okuboyejo, \& Dickson, 2017; Muithi 2018). If succession does not occur or postponed for too long, there might lead to the closure of family business (Chirapanda, 2020). As Cho, et al., (2017) research in Cameroon's SMFBs showed that $93 \%$ of the business initiators do not consider the sustainability of the businesses after they die and hence do not prepare for succession. Muithi (2018) found that succession planning and family dynamics have the most impact on the sustainability of the SMFBs in Ghana. Ogundele, Idris, and Ahmed-Ogundipe (2012) also posits that many family businesses close down due to lack of adequate planning for succession. Onuoha (2013) state that the lack of succession planning in Nigeria is a serious problem militating against the survival of family-owned businesses as $94.2 \%$ of entrepreneurs do not have a succession plan. PwC Family Business Survey (2016) on Australian family businesses found that (i) only $15 \%$ of family businesses have a succession plan for passing governance and ownership of the company to the next in line family members; (ii) more than $60 \%$ agree that business strategies, both corporate and management need to be well established along with a well thought-out succession plan to improve chances of the family business' success. A recent survey in Malaysia suggested that $68 \%$ of those with no next generation family members in the business planned to pass on management and/or ownership to the next generation, while $75 \%$ of those who already have next generation family members working in the business planned to pass on management and/or ownership to the next generation (Family Business Survey, 2018: The Malaysian Chapter, 2019). Ironically, the same research pointed out that only $23 \%$ of them have a robust, formalised and communicated plan. These findings indicate that succession planning is critical to family businesses as they are still not rigorous.

Familiness resources and capabilities of sharing knowledge and succession planning that are rooted in the family itself might not be sufficient to achieve sustainable competitive advantages; instead family business needs to build up firm's valuable, rare, imperfectly imitable, and non-substitutable capability such as technology adoption and application to 
create a performance advantage over the competitors. To do so, technology readiness of the family business employees is a prerequisite for technology adoption and application.

\section{Technology Readiness}

Parasuraman (2000) defined technology readiness as the desire of the customers to use and adopt new technology to meet the needs and business goals and life every day. The concept of technological readiness can help organizations and academics to understand different user behaviours in adopting technology-based products and services. Parasuraman (2000) emphasizes individual readiness to be a very important factor and affect the process of adoption of a technology. At a certain level of technological readiness, the individual as a user has a positive or negative view of a technology-based product or service. In general, SMEs need a tool which is easy to use to conduct daily business and reaching the customers. In relation to that, differences among SMFBs in terms of their readiness towards technology are an important source of heterogeneity. Unfortunately, numerous studies suggest that SMEs have a low level of utilization of improved technologies which became the critical challenge confronting the SMEs in the developing countries in enhancing their opportunities and participation in the world trade [World Trade Report, 2016; Asare et al., 2015; Ntwoku et al., 2017; Martin et al., 2013). The reasons behind were SMEs generally lack of resources and digital competence such as knowledge and skills to apply new technologies in their operations (Prasanna, et al., 2019).

There are a lot of advantages offered to SMEs when using the IT in business. Some of them are; (1) increase business competitive advantage; (2) created changes in business process; (3) facilitated relationship between SMEs market parties; (4) enhance business performance; (5) lower production and labor costs; and (6) add product values (Rokhim et al., 2018). A recent SME CEO Forum on how digital economy will disrupt businesses in Malaysia acknowledged that although there are many concerns in digitising businesses, SMEs can no longer rely on traditional processes in a digitally transformed world (Low, 2018). According to the Business Today (2018), SMEs in Malaysia would need to view technology as an investment rather than a cost for sustainable growth. Technology is the critical factor influencing the survival of the SMEs in the globalized era. Technological progress is one of the theoretically accepted measures applied to eliminate the frontier barrier of an economy because it helps to increase the productivity and efficiency of factors of production of the economy such as labor, capital, and other resources, and increase the production input usage in the production (Prasanna, et al., 2019). Moreover, it also found that IT used in SMEs has changed its nature of conducting business to be more productive (Rokhim et al., 2018). Hence, readiness to technology is important since the trend of profit maximization by the large company was not seen in the SMEs. Looking at the importance of technology adoption in running and sustaining the business, current research aims to examine the moderation effects of technology readiness in the relationship between knowledge sharing and SEW of SMFBs and the relationhsip of succession planning and SEW of SMFBs.

This study anticipates that if the family business can be passed on to the younger generation who are computer-savvy and ready to adopt technology in running the business, business will be able to last longer. Technological readiness has been widely used as a moderator in studies related to online purchasing behavior in the field of marketing where many studies have found that consumer readiness can strengthen the relationship between 
independent variables and online shopping behavior (Aziz \& Wahid, 2018). However, studies that measure the effect of technology readiness in the entrepreneurship field such as family business is still lacking. Furthermore, the concept of technology readiness as a moderator has not yet been explored by other researchers, especially regarding the relationship between knowledge sharing, succession planning and sustainability of SMFBs. Therefore, this study would like to hypothesize that:

H1 Knowledge sharing will have a positive impact on SEW of SMFBs.

$\mathrm{H} 2$ Succession planning will have a positive impact on SEW of SMFBs.

H3 When technology readiness is high, it will strengthen the relationship between knowledge sharing and SEW of SMFBs.

$\mathrm{H} 4$ When technology readiness is high, it will strengthen the relationship between succession planning and SEW of SMFBs.

Figure 1 below indicates the proposed framework;

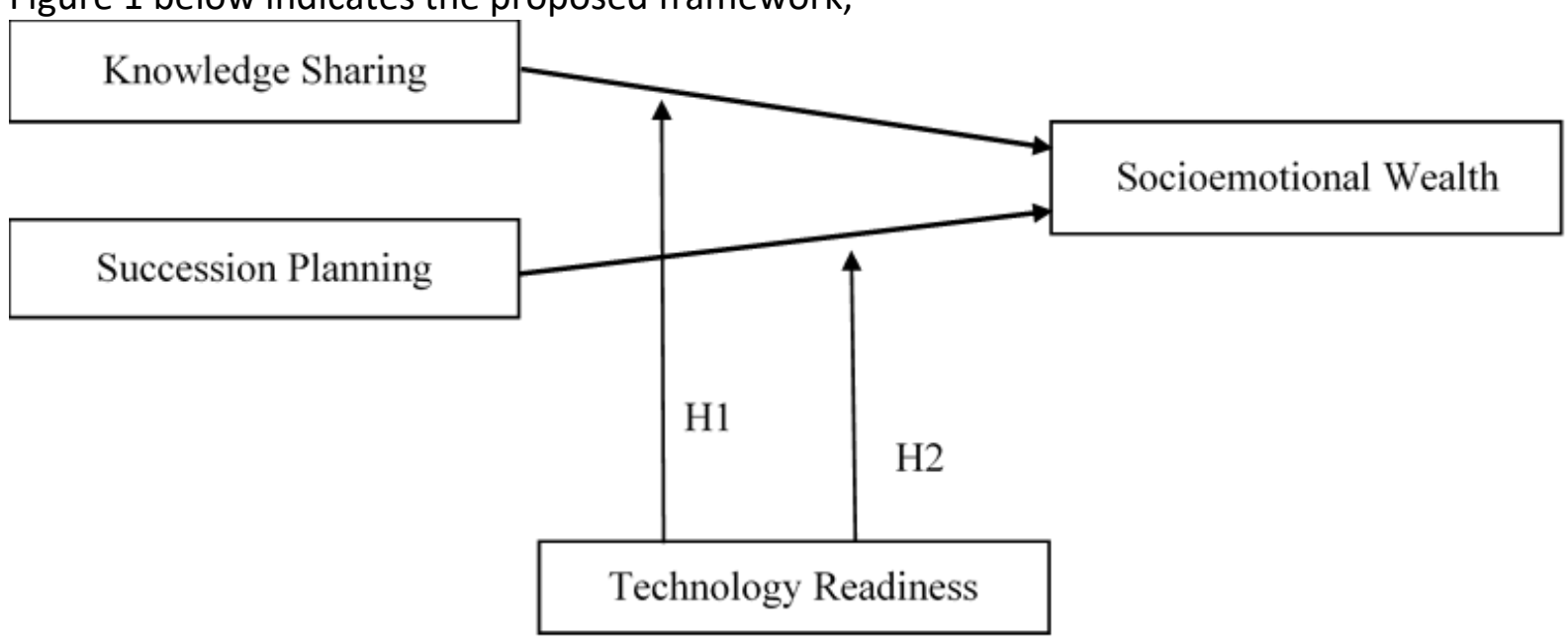

Figure 1: Framework

\section{Conclusion}

This research proposes that the family-specific resources such as knowldge sharing among family members will contribue to the attainment of SMFBs' SEW. On top of that, the capability of the family business in strategic succesion planning will also effect the preservation of SMFBs' SEW. Nevertheless, it is expected that techonology readiness of SMFBs will reinforce the relationship between knowledge sharing and SEW as well as succession planning and SEW. As SMEs are generally lagging behind the performance of big firms due to constraints such as insufficient adoption of innovation and technology, finance and skillful workers, the results of the study may alert and provide practical guidelines to SMFBs on the importance of family-specific resources such as knowldge sharing, and capability such as successsion planning and technology readiness in preserving the SEW.

\section{References}

Ahmad, F. (2017), Knowledge sharing in a non-native language context: challenges and strategies, Journal of Information Science, 24/2, 248-264.

Ahmad, N., \& Daghfous, A. (2010). Knowledge sharing through inter-organizational knowledge networks: Challenges and opportunities in the United Arab Emirates. European Business Review, 22(2), 153-174. 
Alonso-Dos-Santos, M., \& Llanos-Contreras, O. (2019). Family business performance in a postdisaster scenario: The influence of socioemotional wealth importance and entrepreneurial orientation. Journal of Business Research, 101, 492-498.

Asare, R., Akuffobe, M., Quaye, W., \& Atta-Antwi, K. (2015). Characteristics of micro, small and medium enterprises in Ghana: gender and implications for economic growth. African Journal of Science, Technology, Innovation and Development, 7(1), 2635.

Astrachan, J. H., \& Jaskiewicz, P. (2008). Emotional returns and emotional costs in privately held family businesses: Advancing traditional business valuation. Family Business Review, 21, 139-149.

Aziz, N. N. A., \& Wahid, N. A. (2018). Why Consumers are Hesitant to Shop Online: The Major Concerns towards Online Shopping. International Journal of Academic Research in Business and Social Sciences, 8(9), 1175-1185.

Baird, L., \& Henderson, J. C. (2001). The Knowledge Engine. San Francisco: BK.

Baixauli-Soler, J. S., Belda-Ruiz, M., \& Sánchez-Marín, G. (2021). Socioemotional wealth and financial decisions in private family SMEs. Journal of Business Research, 123, 657-668.

Berrone, P., Cruz, C., \& Gómez-Mejía, L. R. (2012). Socioemotional wealth in family firms: Theoretical dimensions, assessment approaches, and agenda for future research. Family Business Review, 25/3, 258-279. https:// doi.org/10.1177/0894486511435355

Business Today. (2018). SMEs should embrace technology as a business enabler, say SAP and MDEC. Retrieved Jan 29, 2020, from

https://www.businesstoday.com.my/2018/09/21/smes-should-embrace-technologyas-business-enabler-say-sap-and-mdec/

Cabrera-Suárez, K., De Saá-Pérez, P., \& García-Almeida, D. (2001). The succession process from a resource-and knowledge-based view of the family firm. Family Business Review, 14/1, 37-46.

Chirapanda, S. (2020). Identification of success factors for sustainability in family businesses. Journal of Family Business Management, 10/1, 58-75.

Chirico, F. (2008a). The creation, sharing and transfer of knowledge in family business. Journal of Small Business and Entrepreneurship, 21/4, 413-434.

Chirico, F. (2008b). Knowledge accumulation in family firms: Evidence from four case studies. International Small Business Journal, 26, 433-462.

Cho, N. M., Okuboyejo, S., \& Dickson, N. (2017). Factors Affecting the Sustainability of Family Businesses in Cameroon: An Empiri cal Study in the Northwest and Southwest Regions of Cameroon. Journal of Entrepreneurship: Research and Practice, 2-19.

Chrisman, J. J., Chua, J. H., Pearson, A. W., \& Barnett, T. (2012). Family involvement, family influence, and family-centered non-economic goals in small firms. Entrepreneurship Theory and Practice, 36/2, 267-293.

Chua, J. H., Chrisman, J. J., \& Sharma, P. (1999). Defining the family business by behavior. Entrepreneurship Theory \& Practice, 23/4, 19-39.

Cunningham, J., Seaman, C. \& Mcguire, D. (2017). Perceptions of knowledge sharing among small family firm leaders: a structural e quation model. Family Business Review, 30/2, 160-181.

Debicki, B. J. (2012). Socioemotional wealth and family firm internationalization: The moderating effect of environmental munificence. A Dissertation, Mississippi State University, Mississippi. 
Debicki, B. J., Kellermanns, F. W., Chrisman, J. J., Pearson, A. W., \& Spencer, B. A. (2016). Development of a socioemotional wealth importance (SEWi) scale for family firm research. Journal of Family Business Strategy, 7/1, 47-57.

Debicki, B. J., Van de Graaff Randolph, R., \& Sobczak, M. (2017). Socioemotional wealth and family firm performance: a stakeholder approach. Journal of Managerial Issues, 82-111.

Eddleston, K. A., Kellermanns, F. W., \& Sarathy, R. (2008). Resource configuration in family firms: Linking resources, strategic planning and technological opportunities to performance. Journal of Management Studies, 45/1, 26-50.

Gomez-Mejia, L. R., Haynes, K. T., Nunez-Nickel, M., Jacobson, K. J., \& Moyano-Fuentes, J. (2007). Socioemotional wealth and business risks in family-controlled firms: Evidence from Spanish olive oil mills. Administrative Science Quarterly, 52, 106-137.

Grant, R. M. (1996). Prospering in dynamically-competitive environments: Organizational capability as knowledge integration. Organization Science, 7/4, 375-387.

Hauck, J., Prügl, R. (2015). Innovation activities during intra-family leadership succession in family firms: An empirical study from a socioemotional wealth perspective. Journal of Family Business Strategy, 6/2, 104-118. https://doi.org/10.1016/j.jfbs.2014.11.002

Jiang, D. S., Kellermanns, F. W., Munyon, T. P., \& Morris, M. L. (2018). More than meets the eye: A review and future directions for the social psychology of socioemotional wealth. Family Business Review, 31/1, 125-157.

Jones, C. D., Makri, M., \& Gomez-Mejia, L. R. (2008). Affiliate directors and perceived risk bearing in publicly traded, family-controlled firms: The case of diversification. Entrepreneurship Theory and Practice, 32/6, 1007-1026.

Lin, W. B. (2013). Research on knowledge sharing and interpersonal relationships: Empirical study of family firms and non-family firms. Quality \& Quantity, 47/1, 151-166. DOI 10.1007/s11135-011-9509-y.

Low, C. (2018). SME CEO forum 2018 - How the digital economy will disrupt businesses in Malaysia. Retrieved Jan 29, 2020, from Kaodim website: https://comms.kaodim.com/2018/10/25/sme-ceo-forum-2018-digitising-smes-acrosssoutheast-asia/

Loy, J. T. C. (2010). Dynasting across cultures: A grounded theory of Malaysian Chinese family firms. A Dissertation, University of Minnesota.

Martin, F. M., Ciovica, L., \& Cristescu, M. P. (2013). Implication of Human Capital in the Development of SMEs through the ICT Adoption. Procedia Economics and Finance, 6 , 748-753.

Miller D., Le Breton-Miller I., \& Lester, R. H. (2010). Family ownership and acquisition behavior in publicly-traded companies. Strategic Management Journal, 31/2, 201-223

Muithi, F. M. (2018). Factors affecting the sustainability of family businesses in Ghana after the exit of first generation of founding family members (Doctoral dissertation).

Németh, K., \& Németh, S. (2018). The Relationship Between The Socioemotional Wealth And The Family Businesses'sustainability. Management, 16, 18.

Ntwoku, H., Negash, S., \& Meso, P. (2017). ICT adoption in Cameroon SME: application of Bass diffusion model. Information Technology for Development, 23/2, 296-317.

O'Dell, C., \& Grayson, C. J. (1998), If only we knew what we know: Identification and transfer of internal best practice. California Management Review, 40/3, 154-174.

Omar, C. M. Z. C. (2019). Small and medium enterprises (SME): contribution and challenges. International Journal of Research in Commerce and Management Studies, 1/1, 53-59. 
Ogundele, O. J. K., Idris, A. A., \& Ahmed-Ogundipe, K. A. (2012). Entrepreneurial succession problems in Nigeria's family businesses: A threat to sustainability. European Scientific Journal, 8/7, 208-227.

Onuoha, B. C. (2013). Poor succession planning by entrepreneurs: The bane of generational enterprises in South-East, Nigeria. AFRREV IJAH: An International Journal of Arts and Humanities, 2/2, 270-281.

Parasuraman, A. (2000). Technology Readiness Index (TRI) a multiple-item scale to measure readiness to embrace new technologies. Journal of service research, 2/4, 307-320.

Prasanna, R. P. I. R., Jayasundara, J. M. S. B., Gamage, N., Kumara, S., Ekanayake, E. M. S., Rajapakshe, P. S. K., \& Abeyrathne, G. A. K. N. J. (2019). Sustainability of SMEs in the Competition: A Systemic Review on Technological Challenges and SME Performance. Journal of Open Innovation: Technology, Market, and Complexity, 5(4), 100.

PwC Global Family Business Survey: Focus on Malaysia. (2015). Up close and professional: the family factor. Retrived from https://www.pwc.com.

PwC. (2016): The family business sector in 2016. Success and succession. Retrived from https://www.pwc.com/gx/en/services/family-business/family-business-survey2016/succession.html

PwC Global Family Business Survey. (2018). The value effect. Retrived from https://www.pwc.com/gx/en/services/family-business/family-business-survey2018.html.

PwC Family Business Survey 2018: The Malaysian Chapter. (2019): The values effect. Retrieved from https://www.pwc.com/my/en/ assets/publications/2019/family-bizsurvey-2018v2.pdf

Poza, E. J. (2004). Family Business.Thomson/South-Western.

Rokhim, R., Wulandari, P., \& Mayasari, I. (2018). Small medium enterprises technology acceptance model: A conceptual review. International Journal of Business and Society, 19, 689-699.

Rothwell, W. (2001). Effective succession planning. New York: American Management Association

Schepers, J. \& Voordeckers W. \& Steijvers, T. \& Laveren, E. (2014). The entrepreneurial orientation-performance relationship in private family firms: The moderating role of socioemotional wealth. Small Business Economics, 43/1, 39-55.

Schulze, W. S., Lubatkin, M. H., Dino, R. N., \& Buchholtz, A. K. (2001). Agency relationships in family firms: Theory and evidence. Organization Science, 12/2, 99-116.

Sharma, P., Chrisman, J. J., \& Chua, J. H. (1997). Strategic management of the family business: Past research and future challenges. Family Business Review, 10/1, 1-36.

Sirmon, D., \& Hitt, M. (2003). Managing resources: Linking unique resources, management and wealth creation in family firms. Entrepreneurship Theory and Practice, 27/4, 339359.

Syed-Ikhsan, S. O. S., \& Rowland, F. (2004). Benchmarking knowledge management in a public organization in Malaysia. Benchmarking: An International Journal, 11/3, 238-266.

Wang, S., \& Noe, R. A. (2010). Knowledge sharing: A review and directions for future research. Human Resource Management Review, 20, 115-131.

Ward, J. L. (1997). Growing the family business: Special challenges and best practices. Family Business Review, 10/4, 323-337.

Westhead, P., \& Cowling, M. (1998). Family firm research: The need for a methodological rethink. Entrepreneurship Theory and Practice, 23/1, 31-56. 
INTERNATIONAL JOURNAL OF ACADEMIC RESEARCH IN BUSINESS AND SOCIAL SCIENCES Vol. 11, No. 11, 2021, E-ISSN: $2222-6990$ @ 2021 HRMARS

Yang, J. (2007). The impact of knowledge sharing on organizational learning and effectiveness. Journal of Knowledge Management, 11/2, 83-90. 